\title{
THE EFFECT OF COW AND SOY MILK CONSUMPTION ON CALCIUM LEVELS OF WISTAR RAT TEETH
}

\author{
Ulya Ahassa*, Putri Kusuma Wardhani**, Indah Titien Soeprihati**
}

\author{
* Postgraduate Students of Pediatric Dentistry, Faculty of Dentistry Gadjah Mada University \\ ** Department of Pediatric Dentistry, Faculty of Dentistry, Gadjah Mada University \\ ** Department of Pediatric Dentistry, Faculty of Dentistry, Gadjah Mada University \\ Correspondence: ulyaahassa@gmail.com
}

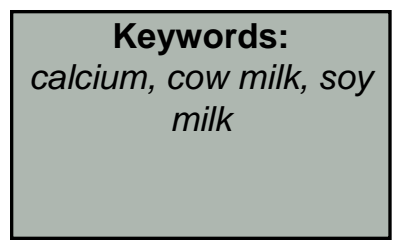

\begin{abstract}
Background: Complementary food (MPASI) is the main food after the child weans from exclusive breastfeeding. One of the main sources of complementary food is milk. Most children are fed with cow's milk, but since some children are lactose intolerant, they will be recommended to consume soy milk. However, soy milk and cow's milk are known to have different amount of calcium as one of the key nutrients for tooth growth and development. The purpose of this study was to compare the effect of cow's milk and soy milk consumption on the calcium concentration of Wistar rat teeth.

Method: Subjects were 27 male Wistar rats aged 1 month old divided into 3 groups, equally with 9 rats in each: groups that consumed cow's milk, soy milk, and control group. The group consuming Cow and soy milk was fed 2 times a day, in the morning and evening for 28 days. Each subject was then euthanized and their mandibular right incisor was taken at the end of the treatment to measure calcium concentration by atomic absorption spectrophotometry.

Result: The results of the one way ANOVA test showed that there were significant differences $(p<0.05)$ in the calcium concentration of incisors in the teeth of rat consuming cow's milk, soy milk, and control group. Hence, it can be concluded that the consumption of cow's milk and soy milk has an effect on the calcium concentration of Wistar rat teeth.

Conclusion: Calcium concentration of Wistar rat teeth that consume cow's milk is higher than those that consume soy milk.
\end{abstract}

\section{INTRODUCTION}

Children aged 6-24 months are fed with complementary foods in addition to breast milk (MPASI) to meet their increasing nutritional needs. Milk, especially cow's milk, is the main source of complementary foods. ${ }^{1}$ Milk consumption is of necessity because it contains essential nutrients for growth and development and maintenance of the body. ${ }^{2}$ However, lactose intolerance is mostly the main reason for a child to avoid consuming cow's milk. $^{3}$

The main components of milk are protein, fat, sugar (lactose), minerals, and water. Cow's milk is a very good source of iodine, calcium, vitamin $D$, riboflavin, and phosphorus. One glass of cow's milk will meet $50 \%$ of the child's daily calcium needs. The interaction between calcium, lactose and vitamin $D$ present in cow's milk provides favorable conditions for the absorption of calcium by the body. ${ }^{4}$

One of the main alternative intakes to substitute 
cow's milk is soy milk. Soy milk is a highly nutritious drink, especially due to its protein content. ${ }^{2}$ One of the advantages of soy milk is that it is consumable for people with lactose intolerants. ${ }^{5}$ The only drawback of soy milk is the lack of calcium amount of only about a quarter of the calcium content of cow's milk. ${ }^{3}$

Calcium is one of the most essential nutrients for tooth growth and development. ${ }^{6}$ at the time of tooth eruption, the enamel mineralization process is yet to complete and thus will continue for approximately 2 to 3 years after the tooth eruption. ${ }^{7}$

Foods that contain digested calcium will enter the intestine and some of the calcium content in these foods will be absorbed by the intestine. The calcium content absorbed by the intestines will get into the bloodstream. ${ }^{8}$ then, blood will distribute calcium throughout the body, through cells, saliva, bones and kidneys. ${ }^{9}$ the amount of calcium distributed to saliva will be used for the tooth remineralization process. ${ }^{10}$

The albino rat (Rattus norvegicus) is the most commonly used animal model in biomedical research. The fact that this animal can represent the biological system of mammals makes it a suitable animal model in pre-clinical studies. ${ }^{11}$ The aim of this study was to compare the effect of cow's milk and soy milk consumption on the calcium level of Wistar rat tooth crowns.

\section{RESEARCH METHOD}

This study was approved by the Ethics Committee, Faculty of Dentistry, Gadjah Mada University, and No.0094/KKEP/FKG-UGM/EC/2019. 27 white Wistar rats aged 1 month were used as the animal model. The rats had previously been weaned for 21 days then adapted in the rat cage for 1 week to adjust to the cage conditions. Twenty seven rats were randomly divided into 3 groups of equally 9 rats for each. The rats in group I were fed with cow's milk twice a day, those in group II were provided with soy milk twice a day, while those in group III as the control group were provided with aquades twice a day.

The dose of administration was determined by converting the human dose to the dose of animal models. Cow's milk was administered at a dose of $0.003456 \mathrm{~g}$ powder $/ \mathrm{g} \mathrm{BW}$ in $0.0216 \mathrm{ml}$ water $/ \mathrm{g} \mathrm{BW}$ of water per 1 serving of drink, and soy milk was provided at a dose of $0.003456 \mathrm{~g}$ powder/g BW in $0.0216 \mathrm{ml}$ water/g BW water per 1 serving of drink. The control group was administered with distilled water. Feeding was carried out for 28 days.

After 28 days of treatment, each rat was euthanized with an overdose ketamine. The lower jaw was removed and then separated and cleaned. The caries-free mandibular right incisor was separated from the bone. The calcium level of the teeth that were separated from the bone was then measured by the Atomic Absorption Spectrophotometry (AAS) method. Afterwards, the results were processed by one way ANOVA test.

\section{RESULT}

Table 1 presents the average incisor calcium levels of 196,189.2 ppm in the group fed with cow's milk. The group consuming soy milk indicated an average incisor calcium level of $184,628.2 \mathrm{ppm}$, while the control group denoted an average incisor calcium level of $173,236.6 \mathrm{ppm}$. This result delineates that the group consuming cow's milk has the highest average of calcium level, while the control group has the lowest average.

The results of the one way ANOVA test in Table 1 denote a significant difference $(p<0.05)$ in the 
calcium levels of the incisors in the group consuming cow's milk, soy milk, and control. Afterwards, the post hoc LSD test was carried out to see the significant differences in calcium levels of the incisors of Wistar rats between groups, and the results are presented in Table 2.

Table 2 depicts the significant difference between the calcium levels of the group consuming cow's milk and the group consuming soy milk, with a significance value $(p)$ of $0.038(p<0.05)$. There were significant differences between the group consuming cow's milk and the control group with a significance value $(p)$ of $0.000(p<0.05)$. There were also significant differences between the group consuming soy milk and the control group with a significance value $(p)$ of $0.041(p<0.05)$.

Table 1. Average and Standard Deviation of Calcium Levels (ppm) in the Incisors of Wistar Rats Consuming Cow's Milk, Soy Milk, and Control and Probability Value of One-way Anova Test

\begin{tabular}{ccccc}
\hline group & $\begin{array}{c}\text { Number of } \\
\text { samples } \\
(\mathbf{n})\end{array}$ & $\begin{array}{c}\text { Calcium level of } \\
\text { incisors (ppm) }\end{array}$ & $\mathbf{F}$ & $\mathbf{p}$ \\
\cline { 2 - 3 } & 9 & $196189,2 \pm 7096,3$ & 9,478 & 0,001 \\
\hline Cow's milk & 9 & $184628,2 \pm 11185,1$ & & \\
\hline Soy milk & 9 & $173236,6 \pm 14132,1$ & & \\
\hline Control & 9 & &
\end{tabular}

Table 2. Results of Post Hoc LSD Test of Calcium Levels between Groups

\begin{tabular}{cccc}
\hline Source & F & $\mathbf{p}$ \\
\hline Cow's milk vs. soy milk & 9,478 & & 0,038 \\
\cline { 1 - 1 } Cow's Milk vs. Control & & 0,000 \\
Soy Milk vs. Control & & 0,041 \\
\cline { 3 - 4 } & &
\end{tabular}

\section{DISCUSSION}

The results imply that the group consuming cow's milk had the highest calcium level compared to all other groups. This different result is probably attributed to the different calcium metabolism of cow's milk and soy milk in the body. The interaction between calcium, lactose, and vitamin D contained in cow's milk allows favorable conditions for the use of calcium by the body. ${ }^{4}$ Cow's milk, besides containing calcium, also contains other ingredients that can increase calcium absorption, including vitamin D and lactose. Lactose is a carbohydrate compound that plays a role in increasing calcium absorption in the intestine, by increasing the solubility of calcium in the intestine so that more calcium is distributed to the saliva. ${ }^{12}$

The calcium level of the teeth of Wistar rats, which consumed cow's milk, was higher than soy milk, apart from being influenced by the systemic effect of saliva secretion, possibly because there was leftover cow's milk in the oral cavity. Cow's milk 
contains protein in the form of casein micelles, which form a stable calcium phosphate complex. The cow's milk that is left in the oral cavity will then mix with saliva and the calcium phosphate complex will break down into $\mathrm{Ca}^{2}+$ ions and $\mathrm{PO}_{4}{ }^{3-}$ ions, so that it will easily get into the enamel porosity. Despite the hard surface of the enamel, the enamel is permeable to ions and molecules that come from the daily consumption of food and beverages. ${ }^{13}$

The process of tooth enamel remineralization can be assisted by the presence of calcium and phosphate minerals present in cow's milk. At first, the calcium and phosphate minerals found in milk will be deposited in the surface layer of the microporosity, and then it will diffuse into the microporosity of the enamel. Minerals can diffuse in all directions between enamel crystals and then absorbed by hypomineralized enamel, or enamel that has previously been demineralized. Thus, the dissolved enamel will rebuild or reconstruct.

The group that consumed soy milk had lower calcium levels than the group fed with cow's milk. The absorption of calcium from soy milk is inhibited by fat, oxalate, phosphate and phytate, which form a complex with calcium in the intestinal space. ${ }^{15}$ Calcium in vegetable milk, can be utilized very little by the body due to inhibiting substances, especially oxalates and phytates. Oxalate and phytic acid will form insoluble calcium oxalate and calcium phosphate, so they cannot be absorbed. The presence of phytic acid will develop into a complex with insoluble minerals, so that it cannot be absorbed. ${ }^{10}$ Calcium absorption in the intestine is inhibited by oxalate by chelating calcium and increasing its excretion through feces. ${ }^{16}$ Cow's milk is a good source of calcium, while the calcium amount of soy milk is very little. ${ }^{17}$

Another possibility is because the calcium in soy milk will form a calcium oxalate and calcium phytate complex. Oxalates and phytates will bind minerals, thereby reducing their solubility and bioavailability. ${ }^{18}$ The low solubility level will makes it difficult for $\mathrm{Ca}^{2}+$ ions to break down so that $\mathrm{Ca}^{2}+$ ions will be impeded from getting into enamel porosity. Cow's milk does not contain oxalates and phytates, and thus $\mathrm{Ca}^{2+}$ ions diffuse more easily into the enamel surface than soy milk.

The results of this study are in line with those revealed by Heaney et al. (2000), who examined the bioavailability of calcium in cow's milk and soy milk. It was found that the body can better absorb calcium from cow's milk than that of soy milk. ${ }^{19}$

\section{CONCLUSION}

The calcium level of Wistar rats' teeth that consumed cow's milk was higher than those that consumed soy milk.

\section{REFERENCES}

1. Listyoningrum, H., dan Harijono, 2015, Optimasi Susu Bubuk dalam Makanan Pendamping ASI, Jurnal Pangan dan Agroindustri, 3(4):13021312.

2. Jarmani, N.S., 2005, Peranan Perempuan dalam Mengatasi Kemiskinan dan Meningkatkan Kualitas Konsumsi Gizi Keluarga Melalui Budidaya Ayam Kampung di Daerah Urban dan Pedesaan, hal 294-7.

3. Egayanti, Y., 2008, Kenali Intoleransi Laktosa Lebih Lanjut, Infopom Jan, 9(1):1-3.

4. Atherton, H.V., dan Newlander, J.A., 1982, Chemistry and Testing of DairyProducts, Fourth Edition, Avi Publishing Company Inc., Westport, Connecticut.

5. Koswara, 2006, Susu Kedelai Tak Kalah dengan Susu Sapi, http://www.ebookpangan.com

6. Nizel, A.E., 1981, Nutrition in Preventive Dentistry: Science and Practice, Second 
Edition, WB. Saunders, New York.

7. Sumartono, S.H., 1991, Masalah Karies Gigi Anak, Buku Naskah Ilmiah KPPIKG-IX, 392-7

8. Guyton, A.C., dan Hall, J.E., 2006, Textbook of Medical Physiology, Eleventh Edition, Elsevier Saunders, Philadelphia.

9. Tordoff, M.G., 2001, Calcium: Taste, Intake, and Appetite, American Physiological Society, Physiological Reviews 81(4):1567-1597.

10. Almatsier, S., 2004, Prinsip Dasar Ilmu Gizi, PT Gramedia Pustaka Utama, Jakarta.

11. Sengupta,P., 2013,The Laboratory Rat: Relating Its Age with Human's, International Journal of Preventive Medicine, 4(6):624-630.

12. Abrams, S.A., Griffin, I.J., dan Davila, P.M., 2002, Calcium and Zinc Absorption from Lactose-Containing and Lactose-Free Infant Formulas, Am J Clin Nutr, 76:442-446.

13. Yuliarti R. T., Suwelo I. S., dan Soemartono, S. H., 2013, Kandungan Unsur Flour pada Email Gigi Tetap Muda dengan Tumpatan Semen
Ionomer Kaca Viskositas Tinggi, Journal of Dentistry Indonesia, 15(2):163-8.

14. Fejerskov, O., dan Kidd, E., 2008, Dental Caries: The Disease and Its Clinical Management, Blackwell Munksgaard, UK.

15. Emslie-Smith, D., Paterson C., Scratcherd, T., dan Read, N.W., 1988, Textbook of Physiology, Eleventh Edition, ELBS, Singapura.

16. Gropper, S. S., Smith, J. L., dan Groff, J.L, 2005, Advanced Nutrition and Human Metabolism, Thomson Wadsworth, Bellmont, California.

17. Miller, G.D., Jarvis, J.K.., dan McBean, L.D., 2000, The Importance of Milk and Milk Products in the Diet, Handbook of Dairy Foods and Nutrition, Second Edition, CRC Press, Florida.

18. Ink, S. L, 1988, Fiber-Mineral and Fiber-Vitamin Interactions, Marcel Dekker Inc., New York.

19. Heaney, R., Dowell, M., Rafferty, K., dan Bierman, J., 2000, Bioavaibility of The Calcium in Fortified Soy Imitation Milk, Am J Clin Nutr,71:1166-9. 